\title{
Correlation between the Clinical Symptoms and the Proportion of Mitochondrial DNA Carrying the 8993 Point Mutation in the NARP Syndrome
}

\author{
PÄIVI MÄKELÄ-BENGS, ANU SUOMALAINEN, ANNA MAJANDER, JUHANI RAPOLA, \\ HANNU KALIMO, AULI NUUTILA, AND HELENA PIHKO
}

Department of Human Molecular Genetics [P.M.-B., A.S.], National Public Health Institute, Helsinki; Department of Child Neurology and Paediatrics [P.M.-B., J.R., H.P.], Children's Hospital, University of Helsinki; Department of Medical Chemistry [A.M.], Helsinki Bioenergetics Group, Institute of Biomedical Sciences, University of Helsinki; Department of Pathology [H.K.], University of Turku, Turku, Finland; and Seinäjoki Hospital [A.N.], Seinäjoki, Finland \begin{abstract}
We describe a four-generation family with a maternally
inherited mitochondrial disorder. The symptoms were restricted to the CNS and muscle, the most common features being subacute necrotizing encephalomyopathy, cognitive impairment, ataxia, retinitis pigmentosa, infantile spasms, and optic atrophy. A point mutation at the nucleotide 8993 of the gene encoding subunit 6 of the ATP synthase, associated with the neurogenic muscle weakness, ataxia, retinitis pigmentosa (NARP) syndrome, was shown to be inherited maternally in this family, and a clear correlation was found between the clinical severity of the disease and the proportion of mutant mtDNA. Analysis of oxidative phosphorylation in mitochondria carrying $80 \%$ mutant mitochondrial DNA showed a reduction of the ATP
\end{abstract}

generation rate coupled to substrate oxidation. (Pediatr Res 37: 634-639, 1995)
mtDNA, mitochondrial DNA
Abbreviations
NARP, neurogenic muscle weakness, ataxia, retinitis pigmentosa
nt, nucleotide
LHON, Leber hereditary optic neuroretinopathy
MELAS, mitochondrial encephalomyopathy, lactic acidosis
and strokelike episodes
CT, computerized tomography
PCR, polymerase chain reaction

Point mutations of mtDNA are associated with a number of maternally inherited diseases. The most frequent of these diseases are LHON (1), MELAS (2, 3), myoclonus epilepsy and ragged-red fibers (4), and NARP syndromes (5). The point mutations are usually heteroplasmic; both normal and mutant mtDNA are present in the same subject. In LHON, the majority of the families have been reported to be homoplasmic for the two most common mutations, but low-level heteroplasmy has also been described $(6,7)$.

The proportion of mutant mtDNA may vary in the offspring of one mother as well as in different tissues of the same individual. This is most probably caused by different proportions of mutant mtDNA in the mitochondria of ova and random distribution of these organelles into different cell types in embryogenesis.

Received June 21, 1994; accepted December 6, 1994

Correspondence: Päivi Mäkelä-Bengs, Department of Human Molecular Genetics, National Public Health Institute, Mannerheimintie 166, FIN-00300 Helsinki, Finland.

Supported in part by the Arvo and Lea Ylppö Foundation, the Sigrid Juselius Foundation, the Emil Aaltonen Foundation, and the Academy of Finland (M.R.C).
NARP syndrome is associated with a heteroplasmic mtDNA point mutation, a $\mathrm{T} \rightarrow \mathrm{G}$ change at nt 8993 of mtDNA (5) of the gene encoding the subunit 6 of $\mathrm{F}_{1} \mathrm{~F}_{0}$ ATP synthase. Two patients with Leigh's syndrome have been described with a $\mathrm{T} \rightarrow \mathrm{C}$ change (8) at the same nucleotide. These nucleotide changes substitute arginine (5) or proline (8) for leucine. The former amino acid change has been shown to inhibit $\mathrm{H}^{+}$ translocation in Escherichia coli ATP synthase (9).

The 8993 point mutation has also been found to be associated with phenotypes other than NARP itself, including Leigh's syndrome, i.e. subacute necrotizing encephalomyopathy (10), psychomotor retardation, seizures, infantile spasms, and dementia $(8,11-16)$. Morphologic findings typical of mitochondrial myopathy, such as ragged-red fibers, have not been found in association with this point mutation $(5,11-13$, 17).

We studied a four-generation family with the mtDNA 8993 $\mathrm{T} \rightarrow \mathrm{G}$ point mutation. The proportion of mutant mtDNA was accurately determined using the solid-phase minisequencing method (18-21), and the symptoms of the patients correlated with the proportion of mutant mtDNA. The effect of mutant 
mtDNA on oxidative phosphorylation was analyzed in mitochondria isolated from cultured patient lymphoblasts.

\section{METHODS}

\section{Subjects}

Figure 1 shows the pedigree with the maternally inherited mitochondrial disorder, and Table 1 summarizes the clinical findings in the family members.

Subjects with no or mild symptoms. II/1, 5-8, 10, and 11, and III/7 and 9 had no record of ill health. Two of them, II/6 and 8 , underwent ophthalmologic examination, and no abnormality was found. Subjects I/1-2, II/2-4, III/1 and 8 , and IV/1 were examined by us. An ophthalmologic examination was performed on subjects $\mathrm{I} / 2, \mathrm{III} / 1$, and IV $/ 1$, and neither retinitis pigmentosa nor optic atrophy was present, although subject III/1, a 37-y-old woman, had recently noticed visual impairment in the dark. Subjects I/2 and II/ 8 had migraine. The other subjects were either healthy or suffered from diseases that were probably acquired (cancer of the ovary, glaucoma, high blood pressure).

Patients. II/9, III/2 and 6, and the two deceased infants, IV/2 and 3, were examined by us. Results from previous examinations, including ophthalmologic follow-up, were available from hospital records. Records were also available for the three other deceased patients, III/3-5.

Patient II/9 was a mildly mentally retarded, visually handicapped 50-y-old man at the time of examination. He had had migraine since childhood and learning problems at school. Retinitis pigmentosa and cognitive impairment were diagnosed at the age of $30 \mathrm{y}$. He was slender, and his height was +0.5 SD. $\mathrm{He}$ had neither ataxia nor muscle weakness. Cerebral and cerebellar atrophy was detected by CT scanning, and the sensory potentials could not be elicited in electroneuromyography.

Patient III/2 was a visually handicapped 35 -y-old woman with cognitive impairment and a mild sensorineural hearing deficit. She had learning difficulties at school. Retinitis pigmentosa was diagnosed at the age of 14 , after which her vision had gradually deteriorated. She was slender, but had neither muscle weakness nor ataxia. Her height was +1 SD.

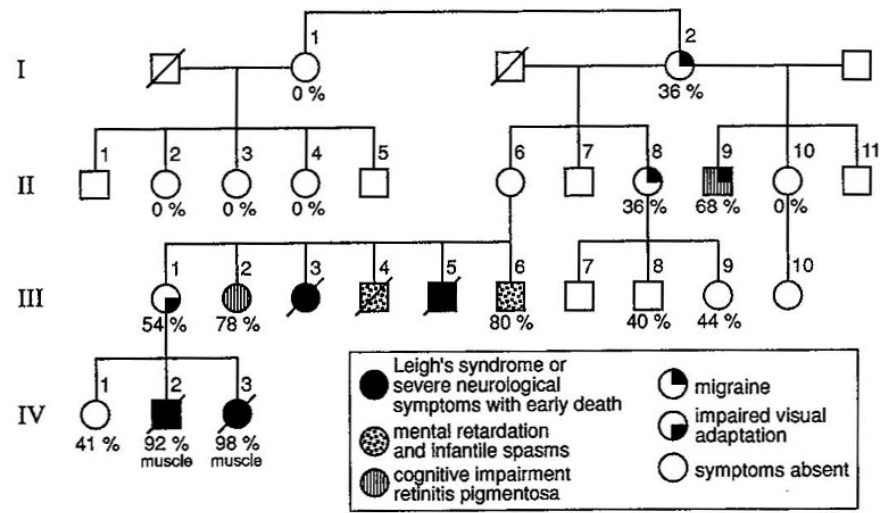

Figure 1. Family pedigree showing the symptoms of the subjects with 8993 $T->G$ mutation and the proportion of mutant mtDNA in leukocytes, except in patients IV/2,3 of whom the proportion of mutant mtDNA was determined from muscle.
Patient III/3 developed normally until the age of $2.5 \mathrm{mo}$, when she began to have seizures. A small ventricular septal defect was suspected because of a cardiac murmur. She died suddenly of pneumonia at the age of $3.5 \mathrm{mo}$. An autopsy was refused.

Patient III/4 developed normally until the age of $6 \mathrm{mo}$, when infantile spasms manifested themselves. Hypsarrhythmia was detected in an EEG, and he was treated with ACTH, followed by phenobarbital and phenytoin, but without response. At the age of $8 \mathrm{y}$ he was severely mentally retarded and hypotonic with brisk tendon reflexes and an unsteady gait, his vision and the optic fundi were normal, but visual impairment developed later. He died of pneumonia at the age of 17 . An autopsy was refused.

Patient III/5 was hypotonic and had a high-pitched cry after birth. He needed to be tube-fed and began to have seizures with apneic spells at the age of 6 mo. At that time he was severely retarded and floppy. Optic atrophy and retinal degeneration were noted on neuroophthalmologic examination. His electroneuromyographic examination was normal. He developed poorly and died of pneumonia at the age of $1 \mathrm{y}$. An autopsy was refused.

Patient III/6 developed normally until the age of 5 mo when hypotonia was detected. Infantile spasms with hypsarrhythmia manifested themselves in EEG at the age of $9 \mathrm{mo}$, and frequent seizures continued until $2 \mathrm{y}$ of age in spite of anticonvulsive medication. He learned to speak and walk after the age of $2 y$, but suffered from ataxia and vomiting. Retinitis pigmentosa was discovered at the age of 10 . Muscle power and tendon reflexes were normal, but he fatigued easily during sustained physical activity. At present he is $20 \mathrm{y}$ of age, mentally retarded, and visually handicapped.

Patient IV/2 was examined after birth owing to reduced responsiveness. He was tube-fed and began to have extension fits with apneic spells at the age of 4 mo. His EEG was progressively abnormal with periodic spike and wave bursts and low-voltage background activity. Generalized atrophy was seen in CT scanning. He had optic atrophy and retinal degeneration. The visual evoked potentials could not be elicited. At the age of 7 mo he was floppy and severely mentally retarded with poor reaction to sounds. He died of pneumonia at the age of $2 \mathrm{y}$. An autopsy was refused.

Patient IV/3 was hypotonic after birth, and her motor development was slow. From the age of 6 mo she had extension fits and apneic spells, and on examination she was floppy and retarded with poor visual contact. Her condition worsened rapidly, and she died of respiratory failure at the age of $7 \mathrm{mo}$. General and neuropathologic autopsy studies were performed, and all the structural alterations detected were compatible with the Leigh's syndrome.

Tests of sera and cerebrospinal fluid. Tests revealed occasionally elevated blood lactate values, up to $5.2 \mathrm{mmol} / \mathrm{L}$ (nor$\mathrm{mal},<1.6 \mathrm{mmol} / \mathrm{L}$ ) in the severely affected infants. Cerebrospinal fluid was studied in six patients, and it did not contain increased amounts of protein. The cerebrospinal fluid lactate value of patient II/9 was within the normal range. 
Table 1. Clinical findings in the symptomatic members of the family

\begin{tabular}{|c|c|c|c|c|c|c|c|c|c|}
\hline \multirow[b]{2}{*}{ Findings } & \multicolumn{9}{|c|}{ Patient } \\
\hline & III-3 & IV-3 & III-5 & IV-2 & III-4 & III-6 & III-2 & II-9 & III-1 \\
\hline Age at present/at death $\dagger(y)$ & $0.25 \dagger$ & $0.6 \dagger$ & $1 \dagger$ & $2 \dagger$ & $17 \dagger$ & 20 & 34 & 50 & 37 \\
\hline Age of onset (y) & 0.15 & Birth & Birth & Birth & 0.5 & 0.5 & $<15$ & $<15$ & 36 \\
\hline Optic atrophy & n.d. & + & + & + & n.d. & - & - & - & - \\
\hline Retinal degeneration & n.d. & +++ & +++ & +++ & n.d. & ++ & ++ & ++ & $(+)$ \\
\hline Ataxia & - & - & - & - & ++ & + & - & - & - \\
\hline Seizures & +++ & +++ & +++ & +++ & ++ & ++ & - & - & - \\
\hline Cognitive impairment & n.d. & +++ & +++ & +++ & ++ & ++ & + & + & - \\
\hline Migraine & n.d. & n.d. & n.d. & n.d. & - & - & - & + & - \\
\hline Birth weight (g) & 3950 & 4630 & 4130 & 4690 & 4400 & 4890 & 4300 & n.d. & n.d. \\
\hline Height $(\mathrm{cm})$ & n.d. & 55 & 50 & 55 & 52 & 54 & n.d. & n.d. & n.d. \\
\hline Apgar score & n.d. & $8 / 9$ & $7 / 7$ & $7 / 9$ & $9 / 10$ & 10 & n.d. & n.d. & n.d. \\
\hline
\end{tabular}

n.d. $=$ no data, $(+)=$ impaired vision in the dark with normal neuroophthalmologic examination.

\section{Tissue Samples and Cell Cultures}

Subject III/6 underwent needle muscle biopsy. One part of the specimen was frozen at $-70^{\circ} \mathrm{C}$ for mtDNA studies, and another part was fixed in a $2.5 \%$ glutaraldehyde solution for electron microscopic studies. A surgical muscle biopsy specimen from patients IV/2 and 3 was available for light microscopic study. Peripheral venous blood samples with EDTA as the anticoagulant were stored at $-20^{\circ} \mathrm{C}$.

Lymphoblast cell lines were established from two control individuals and patient III/ 6 by EBV transformation of peripheral lymphocytes. Cells were cultured in RPMI 1640 medium supplemented with $25 \mathrm{mmol} / \mathrm{L}$ Hepes, $20 \mathrm{mmol} / \mathrm{L}$ sodium bicarbonate, $17 \%$ FCS, $3.7 \mathrm{mmol} / \mathrm{L}$ L-glutamine, $100 \mathrm{U} / \mathrm{mL}$ penicillin, $100 \mu \mathrm{g} / \mathrm{mL}$ streptomycin, and $0.25 \mu \mathrm{g} / \mathrm{mL}$ amphotericin B (Sigma Chemical Co.).

\section{DNA Analysis}

Total DNA was isolated from leukocytes and tissue samples in accordance with standard procedures (22). The paraffinembedded tissue samples had originally been prepared for histologic studies and had been stored at room temperature for up to $8 \mathrm{y}$. The samples were deparaffinized (23), and DNA was released from cells by a rapid lysis method (24).

The oligonucleotides. Oligonucleotides for PCRs (25) and solid-phase minisequencing reaction (18) were synthesized on a 382A Applied Biosystems DNA/RNA synthesizer (Applied Biosystems Inc., Foster City, CA). The upstream primer, equal to the sequence between nt 8967 and 8988 of mtDNA, was biotinylated. The downstream primer was complementary to the mtDNA sequence between nt 9027 and 9008 . The detection primer for the minisequencing reaction was designed to hybridize adjacent to the nt 8993 mutation site and was homologous to nt 9013-8994. The specific hybridization temperatures for the primers were calculated as per McGraw et al. (26).

PCR. DNA (5 ng) was amplified with the biotinylated upstream primer at $0.2 \mu \mathrm{mol} / \mathrm{L}$, the downstream primer at 1 $\mu \mathrm{mol} / \mathrm{L}$, and the dNTPs at $0.2 \mathrm{mmol} / \mathrm{L}$ concentrations using $1.25 \mathrm{U}$ of Thermus aquaticus (Taq) DNA polymerase (Promega, Madison WI) in $50 \mu \mathrm{L}$ of its buffer on a programmable heating block (MJ Research Inc.). The conditions were as follows: $95^{\circ} \mathrm{C} 5 \mathrm{~min}$, followed by addition of the Taq poly- merase, then 20 cycles as follows: $94^{\circ} \mathrm{C}, 1 \mathrm{~min} ; 60^{\circ} \mathrm{C}, 1 \mathrm{~min}$; and $72^{\circ} \mathrm{C}, 1 \mathrm{~min}$.

Solid phase minisequencing reactions. Reactions were performed essentially as previously described (20). The detection step was modified as follows. The nucleotide-specific minisequencing reaction mixture contained 10 pmol detection primer and $0.25 \mathrm{U}$ Taq DNA polymerase in its buffer and 15 pmol of $\left[{ }^{3} \mathrm{H}\right] \mathrm{dATP}$ (Amersham International plc, Amersham, $\mathrm{UK}), 2.78$ or $2.59 \mathrm{TBq} / \mathrm{mmol}$, to detect the normal $\mathrm{T}^{8993}$, or 15 pmol of $\left[{ }^{3} \mathrm{H}\right] \mathrm{dCTP}$ (Amersham), $2.26 \mathrm{TBq} / \mathrm{mmol}$, to detect the mutant $G^{8993}$. The eluted radioactivity was measured in a liquid scintillation counter (1209 Rackbeta, LKB). The result of the assay is expressed as the ratio between the incorporated $\left[{ }^{3} \mathrm{H}\right] \mathrm{dCTP}$ and the total radioactivity incorporated in each sample. The percentage of mutant mtDNA was calculated from this ratio taking into account the specific activities of the $\left[{ }^{3} \mathrm{H}\right] \mathrm{dNTPs}$ used.

\section{Analysis of Oxidative Phosphorylation}

Mitochondria were isolated from the EBV-transformed lymphoblastoid cells derived from patient III/6 as previously described (27), with two modifications: the cell pellet after the first centrifugation at $10000 \times g$ was resuspended and gently homogenized in $0.25 \mathrm{~mol} / \mathrm{L}$ sucrose and $0.2 \mathrm{mmol} / \mathrm{L}$ EGTA; the final mitochondrial pellet was also resuspended in this buffer.

Carbonyl cyanide $p$-(trifluoromethoxy)phenylhydrazonesensitive ATP generation coupled to substrate oxidation was analyzed fluorometrically in isolated mitochondria with hexokinase and glucose-6-phosphate dehydrogenase (28). Rotenone-sensitive $\alpha$-ketoglutarate:ferricyanide reductase activity was determined in $0.25 \mathrm{~mol} / \mathrm{L}$ mannitol, $10 \mathrm{mmol} / \mathrm{L} \mathrm{KCl}, 10$ $\mathrm{mmol} / \mathrm{L}$ potassium phosphate, $\mathrm{pH} 7.2,0.2 \mathrm{mmol} / \mathrm{L}$ EDTA, 1 $\mathrm{mmol} / \mathrm{L} \mathrm{MgCl} 2,0.5 \mathrm{mmol} / \mathrm{L} \mathrm{ADP}, 10 \mathrm{mmol} / \mathrm{L} \alpha$-ketoglutarate, $0.5 \mathrm{mM}$ L-malate, $0.7 \mathrm{U} / \mathrm{mL}$ hexokinase, $20 \mathrm{mM}$ D-glucose, 2 $\mathrm{mmol} / \mathrm{L} \mathrm{KCN}$, and $0.1 \mathrm{mmol} / \mathrm{L}$ ferricyanide with and without $0.5 \mu \mathrm{mol} / \mathrm{L}$ carbonyl cyanide $p$-(trifluoromethoxy)phenylhydrazone. Ferricyanide reduction was followed at $420-500$ $\mathrm{nm}$, and samples for glucose-6-phosphate determination were acidified with perchloric acid. The glucose-6-phosphate concentration was determined as described elsewhere (28). Protein 
concentrations were assayed with BCA protein assay reagent (Pierce Chemical Co, Oud Beijerland, The Netherlands).

\section{RESULTS}

Clinical examination. The proportion of mutant mtDNA in the leukocytes or muscle of each individual studied is indicated in the pedigree (Fig. 1) and shown in Table 2. The subjects were divided into four groups based on the severity of the clinical symptoms: 1) The most severe form of the disease was a lethal encephalomyopathy giving symptoms immediately after birth and leading to death during infancy or early childhood (subjects III/3 and 5, and IV/2 and 3). The infants had seizures, EEG abnormality, apneic spells, and feeding problems. Optic atrophy and retinal degeneration were present and neuropathologically verified Leigh's syndrome was found in the autopsied case (subject IV/3). Light microscopic examination of the muscle biopsy specimens of patients IV/2 and 3 was normal. 2) In the second group the disease manifested itself during the first year of life as severe mental retardation, ataxia, EEG-verified infantile spasms and retinitis pigmentosa (subjects III/4 and 6). 3) The patients of the third disease group had cognitive impairment and retinitis pigmentosa leading to a severe visual handicap (II/9 and III/2). A mild sensorineural hearing deficit and early-onset migraine were also present. The slowly progressive symptoms manifested themselves during the second or third decade. 4) The most mildly affected subjects had subtle symptoms possibly associated with the disease, e.g. migraine (I/2 and II/8) and slight impairment of visual

Table 2. Results of the quantification of the $8993 \mathrm{~T} \rightarrow G$ point mutation in the samples of the family members, obtained by the solid-phase minisequencing method

\begin{tabular}{|c|c|c|c|c|}
\hline Samples & $\mathrm{CPM}_{\mathrm{C}}$ & $\mathrm{CPM}_{\mathrm{A}}$ & $\begin{array}{c}\mathrm{CPM}_{\mathrm{C}} / \mathrm{CPM}_{\mathrm{A}} \\
+\mathrm{CPM}_{\mathrm{C}}\end{array}$ & $\begin{array}{c}\text { Percent of } \\
\text { mutant } \\
\text { mtDNA* }^{*}\end{array}$ \\
\hline $\mathrm{I} / 1_{\text {Ieukocyte }}$ & 33 & 4780 & 0.007 & 0 \\
\hline$I / 2_{\text {leukocyte }}$ & 4550 & 9320 & 0.33 & 36 \\
\hline II $/ 2_{\text {leukocyte }}$ & 41 & 5420 & 0.0075 & 0 \\
\hline II $/ 3_{\text {leukocyte }}$ & 52 & 4480 & 0.011 & 0 \\
\hline II $/ 4_{\text {leukocyte }}$ & 90 & 6420 & 0.014 & 0 \\
\hline II $/ 8_{\text {leukocyte }}$ & 2230 & 4670 & 0.32 & 36 \\
\hline II $/ 9_{\text {leukocyte }}$ & 5620 & 3210 & 0.64 & 68 \\
\hline II $/ 10_{\text {leukocyte }}$ & 30 & 4140 & 0.007 & 0 \\
\hline III $/ 1_{\text {leukocyte }}$ & 3820 & 3990 & 0.49 & 54 \\
\hline $\mathrm{III} / 1_{\text {muscle }}$ & 2140 & 1790 & 0.54 & 60 \\
\hline III/ $2_{\text {leukocyte }}$ & 7170 & 2420 & 0.75 & 78 \\
\hline III $/ 6_{\text {leukocyte }}$ & 2540 & 781 & 0.76 & 80 \\
\hline $\mathrm{III} / 6_{\text {muscle }}$ & 3980 & 863 & 0.82 & 85 \\
\hline $\mathrm{III} / 8_{\text {leukocyte }}$ & 3020 & 5640 & 0.35 & 40 \\
\hline III $/ 9_{\text {leukocyte }}$ & 1400 & 2210 & 0.39 & 44 \\
\hline IV $/ 1_{\text {leukocyte }}$ & 2010 & 3500 & 0.36 & 41 \\
\hline $\mathrm{IV} / 2_{\text {muscle }}$ & 922 & 96.1 & 0.91 & 92 \\
\hline $\mathrm{IV} / 3_{\text {muscle }}$ & 5140 & 119 & 0.98 & 98 \\
\hline $\mathrm{IV} / 3_{\text {brain }}$ & 3350 & 176 & 0.95 & 96 \\
\hline $\mathrm{IV} / 3_{\text {heart }}$ & 1310 & 165 & 0.88 & 91 \\
\hline $\mathrm{IV} / 3_{\text {liver }}$ & 6350 & 1290 & 0.83 & 86 \\
\hline$I V / 3_{\text {kidney }}$ & 2230 & 81.6 & 0.96 & 97 \\
\hline No DNA & 43 & 15 & & \\
\hline
\end{tabular}

* Calculated from the specific activities of the $\left[{ }^{3} \mathrm{H}\right] \mathrm{dNTPs}$ used, as described in "Methods." adaptation in the dark (III/1), although the neuroophthalmologic findings were normal. Some of the subjects were completely asymptomatic.

DNA analysis. The results of mtDNA analysis revealing the proportion of the mutant mtDNA in patients' samples based on the solid-phase minisequencing method are shown in Table 2 and in Figure 1.

Morphologic analysis. Light microscopic examination of the muscle of patient IV/2 or IV/3 did not reveal any significant morphologic changes, but an accumulation of large mitochondria was seen in the electron microscopic examination of the muscle of patient III/6 (Fig. 2).

Analysis of oxidative phosphorylation. Table 3 shows the results of the biochemical analysis of isolated mitochondria. In mitochondria from lymphoblast cells carrying $80 \%$ mutant mtDNA uncoupler-sensitive ATP generation rate coupled to substrate oxidation was $64 \%$ of the control values.

\section{DISCUSSION}

The point mutation at nt 8993 of mitochondrial DNA results in a variety of clinical symptoms ranging from Leigh's syndrome, mental retardation, and ataxia to milder manifestations, such as retinitis pigmentosa $(5,11-17)$. We studied a large

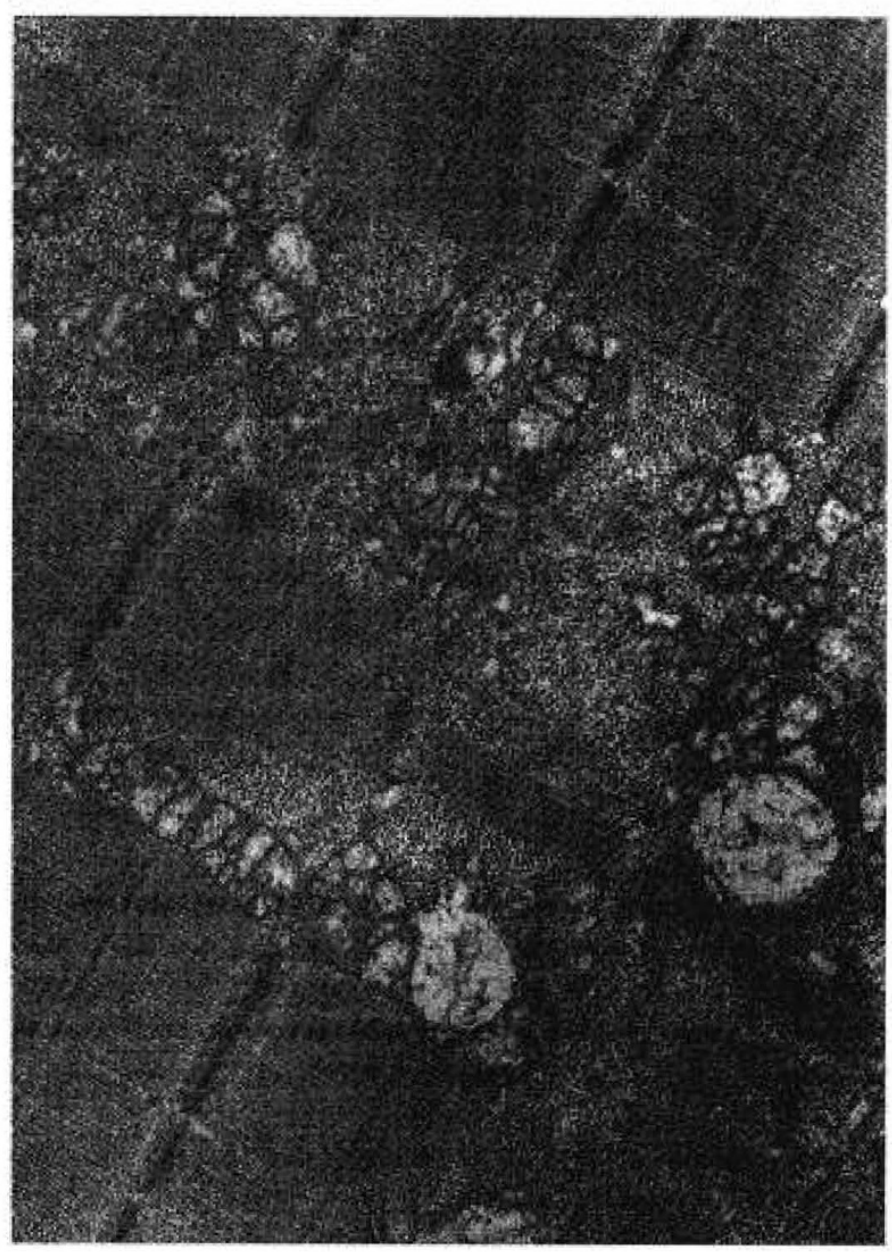

Figure 2. Electron micrograph of the muscle specimen of patient III/6 showing large interfibrillar accumulations of enlarged and vacuolated mitochondria. Magnification $\times 14,000$. 
Table 3. Phosphorylation coupled to the oxidation of $\alpha$-ketoglutarate $(\alpha-K G)$ by ferricytochrome c (cyt c) in mitochondria isolated from lymphoblasts of patient III/6 and two control individuals

\begin{tabular}{|c|c|c|}
\hline Cell line & $\begin{array}{c}\alpha \text {-KG:cyt } c \\
(\mathrm{nmol} / \mathrm{min} \mathrm{mg})\end{array}$ & ATP:2 $\mathrm{e}^{-}$ \\
\hline Patient III/6 $(n=5)$ & $114.4 \pm 33.9$ & $0.89 \pm 0.08$ \\
\hline Controls $(n=7)$ & $97.1 \pm 42.6$ & $1.38 \pm 0.14$ \\
\hline
\end{tabular}

Values for $\alpha$-KG:cyt $c$ correspond to the rate of reduction of ferricyanide expressed as $\mathrm{nmol} / \mathrm{min} \mathrm{mg}$. Mean $\pm \mathrm{SD}$, number of experiments on separate mitochondrial preparations in parentheses.

family in which the 8993 mutation was present in four generations. The clinical symptoms included those mentioned above, as well as infantile spasms and migraine. A remarkable phenotypic variation is a well-known feature of the disorders caused by mtDNA mutations. In our family, the clinical variation was tightly connected with the proportion of mutant mtDNA in the tissues of the patients. Four infants died, of whom two had over $90 \%$ of mutant mtDNA, and one had Leigh's syndrome verified by autopsy. The patient who had $85 \%$ mutant mtDNA in the muscle had severe mental retardation, ataxia, retinitis pigmentosa, and infantile spasms. The patients with $60-80 \%$ mutant mtDNA had cognitive impairment and retinitis pigmentosa, and those with less than $60 \%$ mutant mtDNA had migraine, impairment of visual adaptation in the dark, or were completely asymptomatic. These results are consistent with previous results $(11-13,15)$. However, Shoffner et al. (14) and Yoshinaga et al. (17) found Leigh's syndrome in patients with only $77 \%$ of mutant mtDNA in the brain or $56 \%$ in the muscle, respectively. The variation in the proportion of mutant mtDNA in patients with Leigh's syndrome in different reports cannot be explained by methodologic differences only. The proportion of mutant mtDNA resulting in a specific phenotype may be family specific, e.g. the result of other inherited traits either protecting or making cells more susceptible to mitochondrial dysfunction.

In previous studies the proportion of mutant mtDNA has been determined using electrophoretic separation of restriction fragments after PCR amplication, followed by densitometry. This method has been shown to be semiquantitive because of heteroduplex formation in the last cycle of PCR and overestimation of undigested fragments (29). This is avoided by adding a radioactive nucleotide in the last cycle of PCR (29) or by using the solid-phase minisequencing method, in which the result obtained reflects directly the original proportions of mutant and wild-type mtDNA $(19,20)$.

Of the patient $I / 2$ offspring, one lineage resulted in severely affected individuals including four severely affected infants, who died in early infancy, another lineage was homoplasmic for normal mtDNA, and a third lineage included asymptomatic carriers of the mutation. This finding in this largest family so far described with the 8993 point mutation differs from the previous studies $(5,11,14-16)$ that suggested increasing severity of clinical symptoms and proportion of mutant mtDNA in subsequent generations, i.e. anticipation. Our pedigree shows anticipation-like phenomenon only in one branch, whereas in the others the mutant mtDNA population seems to be disappearing. Possibly a tight "bottleneck" of mtDNA exists in the early phases of embryogenesis, i.e. the number of mtDNA molecules becomes dramatically reduced, and the mtDNA molecules of the fetus originate from a small number of mtDNA copies (30). In Holstein cows it has been shown that a nucleotide at a polymorphic site may change into another reaching homoplasmy in only two generations (30), thus supporting the reduction theory, whereas Howell et al. (31) have demonstrated the conservation of heteroplasmy of a neutral polymorphism over three generations in a LHON family, suggesting the opposite.

Mutant mtDNA has been shown to accumulate in certain cells of affected tissues, whereas others may harbor less mutant mtDNA (32). It has therefore been argued that conclusions about the correlation between a certain phenotype and the proportion of mutant mtDNA cannot be reliably drawn by summing the information of a large number of cells, but should rather be determined by single-cell PCR or in situ hybridization of affected tissue (32). In our patients the severity of the clinical symptoms clearly correlated with the proportion of mutant mtDNA in the leukocytes and muscle samples, and the proportion of mutant mtDNA in the leukocytes was very close to that in the muscle. This finding differs from that in, for example MELAS, in which it has been suggested that selection in rapidly diving tissues is the cause of large differences in the proportion of mutant mtDNA in the muscle and blood (20). The preservation of the 8993 mutation in the leukocytes suggests that the mutation, affecting a protein-coding gene, does not cause very severe dysfunction of the mitochondria.

Inasmuch as the dysfunction of cells in mitochondrial diseases is caused by energy deficiency, direct evidence of disturbed energy metabolism is necessary in each syndrome to demonstrate the pathogenity of a certain mutation. The pathogenic effect of the 8993 mutation has been studied in Escherichia coli, in which the corresponding amino acid substitution was constructed and expressed. The mutation inhibited nearly totally the reverse proton translocation by the $F_{1} F_{0}$ ATPase (9). A decreased ATP synthesis was also previously detected in mitochondria from lymphoblastoid cells derived from a patient carrying the 8993 point mutation in mtDNA. Because respiration rate was not studied in the corresponding conditions the defect could not be assigned to ATP synthase activity alone (33), although the reduction also in the reverse ATPase activity suggested it. We studied ATP synthesis and oxidation activity in lymphoblasts carrying the point mutation and detected a partial reduction in the phosphorylation coupled to substrate oxidation, locating the defect into the ATP synthase specifically. However, the biochemical defect was not as severe as might be expected from the high percentage of mutant mtDNA, or from the profound inhibition of proton translocation activity demonstrated in the E. coli construct (9). Such a difference may be explained by differences in experimental conditions and by different organisms and further studies on the effect of the mutation on oxidative phosphorylation are warranted.

Acknowledgments. The authors gratefully acknowledge the expert advice of Prof. Leena Peltonen and Dr. Ann-Christine 
Syvänen and the assistance of Dr. Ilkka Tarvainen in the investigation of patient II/9.

\section{REFERENCES}

1. Wallace DC, Singh G, Lott MT, Hodge JA, Schurr TG, Lezza AMS, Elsas II LJ, Nikoskelainen EK 1988 Mitochondrial DNA mutation associated with Leber's hereditary optic neuropathy. Science 242:1427-1430

2. Goto Y-I, Nonaka I, Horai S 1990 A mutation in the tRNA ${ }^{\text {Leu(UUR) }}$ gene associated with the MELAS subgroup of mitochondrial encephalomyopathies. Nature 348:651653

3. Kobayashi Y, Momoi MY, Tominaga K, Momoi T, Nihei K, Yanagisawa M, Kagawa $\mathrm{Y}$, Ohta S 1990 A point mutation in the mitochondrial tRNA ${ }^{\text {Leu(UUR) }}$ gene in MELAS (Mitochondrial myopathy, encephalopathy, lactic acidosis and stroke-like episodes. Biochem Biophys Res Commun 173:816-822

4. Shoffner JM, Lott MT, Lezza AMS, Seibel P, Ballinger SW, Wallace DC 1990 Myoclonic epilepsy and ragged-red fiber disease (MERRF) is associated with mitochondrial DNA tRNA ${ }^{\text {Lys }}$ mutation. Cell 61:931-937

5. Holt IJ, Harding AE, Petty RKH, Morgan-Hughes JA 1990 A new mitochondrial disease associated with mitochondrial DNA heteroplasmy. Am J Hum Genet 46:428433

6. Juvonen V, Huoponen K, Syvänen A-C, Nikoskelainen E, Savontaus M-L 1994 quantification of point mutations associated with Leber hereditary optic neuroretinopathy by solid-phase minisequencing. Hum Genet 93:16-20

7. Holt IJ, Miller DH, Harding AE 1989 Genetic heterogeneity and mitochondrial DNA heteroplasmy in Leber's hereditary optic neuropathy. J Med Genet 26:739-743

8. DeVries DD, van Engelen BGM, Gabrels FJ, Ruitenbeek W, van Oost BA 1993 A second missense mutation in the mitochondrial ATPase 6 gene in Leigh's syndrome. Ann Neurol 34:410-412

9. Hartzog PE, Cain BD 1993 The Leu207 $\rightarrow$ Arg mutation in $\mathrm{F}_{1} \mathrm{~F}_{0}$-ATP synthase from Escherichia coli. J Biol Chem 268:12250-12252

10. Leigh D 1951 Subacute necrotizing encephalomyelopathy in an infant. J Neurol Neurosurg Psychiatry 14:216-221

11. Tatuch Y, Christodoulou J, Feigenbaum A, Clarke JTR, Wherret J, Smith C, Rudd N, Petrova-Benedict R, Robinson BH 1992 Heteroplasmic mtDNA mutation $(T \rightarrow G)$ at 8993 can cause Leigh disease when the percentage of abnormal mtDNA is high. Am J Hum Genet 50:852-858

12. Ciafaloni E, Santorelli FM, Shanske S, Deonna T, Roulet E, Janzer C, Pescia G, DiMauro S 1993 Maternally inherited Leigh syndrome. J Pediatr 122:419-22

13. Santorelli FM, Shanske S, Macaya A, DeVivo DC, DiMauro S 1993 The mutation a nt 8993 of mitochondrial DNA is a common cause of Leigh's syndrome. Ann Neurol 34:827-834

14. Shoffner JM, Fernhoff PM, Krawiecki NS, Caplan DB, Holt PJ, Koontz DA, Takei Y, Newman NJ, Ortiz RG, Polak M, Ballinger SW, Lott MT, Wallace DC 1992 Subacute necrotizing encephalopathy: oxidative phosphorylation defects and the ATPase 6 point mutation. Neurology 42:2168-2174

15. Tatuch Y, Pagon RA, Vlcek B, Roberts R, Korson M, Robinson BH 1994 The 8993 mtDNA mutation heteroplasmy and clinical presentation in three families Eur J Hum Genet 2:35-47

16. Puddu P, Barboni P, Mantovani V, Montagna P, Cerullo A, Bragliani M, Molinotti C Caramazza R 1993 Retinitis pigmentosa, ataxia, and mental retardation associate with mitochondrial DNA mutation in an Italian family. Br J Ophthalmol 77:84-88
17. Yoshinaga H, Ogino T, Ohtahara S, Sakuta R, Nonaka I, Horai S 1993 A T-to-G mutation at nucleotide pair 8993 in mitochondrial DNA in a patient with Leigh's syndrome. J Child Neurol 8:129-133

18. Syvänen A-C, Aalto-Setälä K, Harju L, Kontula K, Söderlund H 1990 A primerguided nucleotide incorporation assay in the genotyping of apolipoprotein E. Genomics 8:684-692

19. Suomalainen A, Kollmann P, Octave J-N, Söderlund H, Syvänen A-C 1993 Quantification of mitochondrial DNA carrying tRNA Lys point mutation in myoclonus epilepsy and ragged-red fiber disease. Eur J Hum Genet 1:88-95

20. Suomalainen A, Majander A, Pihko H, Peltonen L, Syvänen A-C 1993 Quantification of tRNA ${ }_{3243}^{\mathrm{Leu}}$ point mutation of mitochondrial DNA in MELAS patients and its effects on mitochondrial transcription. Hum Mol Genet 5:525-534

21. Mariotti C, Tiranti V, Carrara F, Dallapiccolo B, DiDonato S, Zeviani M 1994 Defective respiratory capacity and mitochondrial protein synthesis in transformant Cybrids harboring the tRNA ${ }^{\mathrm{Leu}(U U R)}$ mutation associated with maternally inherited myopathy and cardiomyopathy. J Clin Invest 93:1102-1107

22. Davis LG, Dibner MD, Battey JF 1986 Basic Methods in Molecular Biology. Elsevier Science Publishing Co., New York, pp 47-50

23. Shibata DK, Arnheim N, Martin WJ 1988 Detection of human papilloma virus in paraffin-embedded tissue using the polymerase chain reaction. J Exp Med 167:225230

24. Higuchi R 1989 Simple and rapid preparation of samples for PCR. In; Erlich HA (eds) PCR Technology: Principles and Applications for DNA Amplification. Stockton Press, New York, pp 31-38

25. Mullis KB, Faloona FA 1987 Specific synthesis of DNA in vitro via a polymerasecatalyzed chain reaction. Methods Enzymol 155:335-350

26. McGraw RA, Steffe EK, Baxter SM 1990 Sequence-dependent oligonucleotide-target duplex stabilities: rules from empirical studies with a set of twenty-mers. BioTechniques 8:674-678

27. Majander A, Huoponen A, Savontaus ML, Nikoskelainen E, Wikström M 1991 Electron transfer properties of NADH:ubiquinone reductase in the ND1/3460 and ND4/11778 mutations of the Leber hereditary optic neuroretinopathy (LHON). FEBS Lett 292:289-292

28. Trautschold I, Lambrecht W, Schweitzer G 1985 UV-method with hexokinase and glucose-6-phosphate dehydrogenase. In: Bergmeyer J, Gradßl M (eds) Methods of Enzymatic Analysis. VCH Verlagsgesellschaft, Weinheim, pp 346-357

29. Tanno Y, Yoneda M, Nonaka I, Tanaka K, Miyatake T, Tsuji S 1991 Quantitation of mitochondrial DNA carrying tRNA ${ }^{\mathrm{Lys}}$ mutation in MERRF patients. Biochem Biophys Res Commun 179:880-885

30. Hauswirth WW, Laipis PJ 1982 Mitochondrial DNA polymorphism in a maternal lineage of Holstein cows. Proc Nati Acad Sci USA 79:4686-4690

31. Howell N, Halvorson S, Kubacka I, McCullough DA, Bindoff LA, Turnbull DM 1992 Mitochondrial gene segregation in mammals: is the bottleneck always narrow? Hum Genet 90:117-120

32. Moraes CT, Ricci E, Bonilla E, DiMauro S 1992 The mitochondrial tRNA ${ }^{\text {Leu(UUR) }}$ mutation in mitochondrial encephalomyopathy, lactic acidosis, and stroke-like episodes (MELAS): genetic, biochemical, and morphological correlations in skeletal muscle. Am J Hum Genet 50:934-949

33. Tatuch Y, Robinson BH 1993 The mitochondrial DNA mutation at 8993 associated with NARP slows the rate of ATP synthesis in isolated lymphoblast mitochondria. Biochem Biophys Res Commun 192:124-128 